\title{
Optimization and Characterization of Xylanase from An Indigenous Strain of Aureobasidium Pullulans
}

\author{
Deepak K. Rahi ${ }^{1 *}$, Richa ${ }^{2}$, Maninderjeet Kaur $^{3}$ \\ ${ }^{1}$ Department of Microbiology, Panjab University, Chandigarh, India \\ 2 Department of Microbiology, Panjab University, Chandigarh, India \\ ${ }^{3}$ Department of Microbiology, Panjab University, Chandigarh, India \\ *Corresponding Author: deepakrahi10@ rediffmail.com, Tel.: 9780614540
}

Available online at: www.isroset.org

Received: 18/May/2018, Revised: 30/May/2018, Accepted: 21/Jun/2018, Online: 30/Jun/ 2018

\begin{abstract}
Xylanases are versatile hydrolytic enzymes in nature, due to its degradatory properties and ability to degrade hemicelluloses efficiently. Xylanases and associated debranching enzymes produced by a variety of microorganisms including bacteria, actinomycetes, yeast and fungi bring hydrolysis of hemicelluloses. Among microorganisms, filamentous fungi are the predominant source organism for xylanases. Xylanases have fortified awesome interest because of their potential application in a many industries. Throughout the years, the quantity of conceivable uses of xylanases in the paper and pulp industry has expanded relentlessly, and a few applications have been popularized. In present investigation an indigenous species of Aureobasidium pullulans was evaluated for xylanse producing efficiency and various parameters affecting the production was standardized employing one-factor at a time approach. This resulted in significant enhancement of enzyme activity from 8.7 $\mathrm{U} / \mathrm{ml}$ to $27.75 \mathrm{U} / \mathrm{ml}$. The enzyme optima for $\mathrm{pH}$ and temperature were found to be 6 and $55^{\circ} \mathrm{C}$ respectively.
\end{abstract}

Keywords - Xylanase, Aurobasidium pullulans, optimization, characterization

\section{INTRODUCTION}

In the era of industrialization, enzymes are the focal point of research as it has wide spectrum of uses in various fields. One such enzyme which has been widely explored is xylanase. Xylanases (EC 3.2.1.8) are a class of enzymes which catalyze the cleavage of xylan present in hemicelluloses [1]. There are three types of xylanase, viz., endo-1,4- $\beta$-xylanases, $\beta-1,4$-xylosidases and exoxylanases. The action of enzyme is not at random and it generally acts on non-interrupted sequences with few exceptions [2].

There are multiple sources of xylanases, but microorganisms have been considered as a reliable source of enzymes because they proliferate at tremendously high rates and produce biologically active products that may possess extraordinary properties [3, 4]. It has been observed that fungi are the most sought after sources of enzyme because of their high potential of production of variety of enzymes which also possess high activity and stability over a wide range of $\mathrm{pH}$ and temperature. Enzymes from yeast are also believed to possess the same qualities with having less incubation time for its production in some cases [5]. Xylanases find application in ample number of industries and is majorly used as a supplement in animal feed, manufacture of bread, food and drinks, in the textile industry and in the field of paper and pulp industry.

Industrially, xylanases are important enzymes which are required for the bioconversion of hemicelluloses [1]. The cost involved in the production of enzyme is one of the most important determining factors of its application in industries [6]. Production of enzyme and cost involved depends upon media composition and inducing substrate. Production of xylanases may be carried out in submerged and solid state fermentation. In majority of cases, xylanases are produced in submerged fermentation [7, 8]. It has been found to be advantageous because it is well characterized as well as provides homogenous conditions throughout and scale up process is easier using submerged fermentation [9].

Aureobasidium pullulans is an omnipresent saprophytic fungus. It is also commonly addressed to as black yeast because of its melanin production [10]. It has a high importance in biotechnology for the production of different enzymes, siderophores and pullulan [11]. The potential of $A$. pullulans for production and properties of its extracellular polymeric substances (EPS), pullulan, has been widely studied, unlike its potential of enzyme production. Hence, 
this research work was focused on production of xylanase from an indigenous strain of $A$. pullulans.

Section I contains the introduction of xylanases and the used fungal organism, Section II contain the materials used in the study and the methods by which the study get conducted, Section III contain the results came out after the study and the work supported the study, Section IV concludes the research work with future directions.

\section{Methodology}

\section{Procurement and maintenance of culture}

Pure culture of Aureobasidium pullulans was obtained from the Department of Microbiology, Panjab University, Chandigarh (India) and was maintained on Potato Dextrose Agar slants and preserved at $4{ }^{\circ} \mathrm{C}$.

\section{Detection of extracellular xylanase activity}

\section{Primary screening}

The xylanolytic activity of A. pullulans was screened out by growing the culture on Potato Dextrose Agar (PDA) by supplementing the medium with $0.1 \%$ beech wood xylan. The plates were incubated at $28^{\circ} \mathrm{C}$ for $48-72$ hours followed by staining with $1 \%$ iodine solution and then destained by using $1 \mathrm{mM}$ sodium chloride solution. The zone of clearance formed around the colony was taken as criteria for the degree of extracellular xylanase activity.

\section{Secondary screening}

Inoculum preparation

The 24 hour old culture of $A$. pullulans was inoculated in fresh Potato Dextrose Broth (PDB) medium and was incubated at $28^{\circ} \mathrm{C}$ under shaking. Samples were withdrawn from the flask intermittently to check the number of cells, until the count of $10^{8}$ cells per ml was achieved.

\section{Enzyme production}

$1 \mathrm{ml}$ of the prepared inoculum was added to $50 \mathrm{ml}$ PDB and was incubated for 72 hours at $28^{\circ} \mathrm{C}$ under shaking conditions. The samples were centrifuged at $8000 \mathrm{rpm}$ for 10 minutes to obtain cell free supernatant, which acted as crude enzyme extract.

\section{Xylanase assay}

The xylanase assay was done as per a standard method [12]. For this, $1.80 \mathrm{ml}$ of $0.75 \%$ beech wood xylan was prepared in $0.05 \mathrm{M} \mathrm{Na}$-citrate buffer ( $\mathrm{pH}$ 5.0) which acted as substrate solution. $200 \mu \mathrm{l}$ of enzyme was added to it and were incubated at $50^{\circ} \mathrm{C}$ for 5 minutes. The reaction was terminated by the addition of $3.0 \mathrm{ml}$ of DNSA and the contents were boiled for 15 minutes. After cooling, absorbance was measured at $540 \mathrm{~nm}$. The amount of xylose liberated was quantified using xylose $(0.50 \mathrm{mg} / \mathrm{ml})$ as standard. One International unit of xylanase activity (IU) is defined as the amount of $\mu \mathrm{mol}$ of xylose liberated by $1 \mathrm{ml}$ enzyme per minute under standard assay conditions.
Optimization of physicochemical parameters involved in enzyme production

All the factors involved which affect the production of xylanase was optimized by using conventional one factor at a time (OFAT) approach. This approach was carried out in 250 $\mathrm{ml}$ Erlenmeyer flask containing $50 \mathrm{ml}$ of the selected medium.

Physical parameters

Various factors taken in consideration were optimal production medium (PDB supplemented with 1\% xylan, Czapeck Dox medium, Yeast Mold (YM) medium, YM medium supplemented with PDB components (YM+PDB), Xylan broth medium, and media consisting of different set of essential salts $[5,13,14,15]$, time of incubation $(1,2,3,4,5$, 6 , and 7 days), $\mathrm{pH}(5.0,5.5,6.0,6.5,7.0,7.5,8.0,8.5,9.0$, and 10.0), and inoculum size $(0.25,0.50,1.00,2.00,3.00$, 4.00 , and $5.00 \%$ ).

\section{Biochemical factors}

The carbon sources (arabinose, fructose, galactose, mannose, mannitol, xylose, maltose, sucrose lactose, cellulose, starch and xylan), and nitrogen sources (yeast extract, malt extract, peptone, tryptone, ammonium chloride, ammonium nitrate, ammonium sulphate, sodium chloride, sodium nitrate, potassium chloride and urea) were varied to study their effect on the production. Effect of supplementation of production medium with different additives (tween 20, tween 80, triton $\mathrm{X} 100$, sodium dodecyl sulphate (SDS) and $\beta$ mercaptoethanol) was also studied at different concentrations.

\section{Partial purification}

Partial purification of the enzyme was done by using ammonium sulphate precipitation method [16]. The precipitation was carried out by adding the salt slowly to cold crude enzyme in concentration ranging from 10\%- $90 \%$ with continuous shaking at $4^{\circ} \mathrm{C}$. Then centrifuged at 10000 rpm for 15 minutes and pellet was re-suspended in $5 \mathrm{ml}$ of $0.05 \mathrm{M}$ sodium citrate buffer $(\mathrm{pH} 5)$. It was dialyzed overnight against the buffer at $4^{\circ} \mathrm{C}$ and then checked for enzyme activity.

\section{Characterization of xylanase}

The characterization of xylanase was done to determine temperature and $\mathrm{pH}$ optima and their respective stabilities. For determining the optima of the studied enzyme, the appropriately diluted enzyme was incubated with substrate at different temperature and $\mathrm{pH}$, following which xylanase assay was done to find the residual activity. The effect of temperature and $\mathrm{pH}$ on stability was studied by incubating the enzyme at temperatures ranging from $50^{\circ}-60^{\circ} \mathrm{C}$ and $\mathrm{pH}$ from 4.0 to 8.0 respectively, for 30 and 60 minutes. The xylanase assay was performed to determine the stability. Effects of metal ions on enzyme activity was studied by 
incubating enzyme with equal amounts of metal ions $\mathrm{Mn}^{2+}$, $\mathrm{Na}^{2+}, \mathrm{Ca}^{2+}, \mathrm{Mg}^{2+}, \mathrm{Zn}^{2+}, \mathrm{K}^{+}, \mathrm{Fe}^{2+}$ and $\mathrm{Cu}^{2+}$ ) for 1 hour at $50^{\circ} \mathrm{C}$. Xylanase assay was performed to deduce the residual activity.

\section{Kinetic parameters}

Initially, the xylanase assay was performed at its temperature optima for different time durations. The duration which gave maximum activity was chosen as standard for further assays. To determine the Michaelis-Menten constant $\left(K_{m}\right)$ and catalytic constants $\left(K_{\text {cat }}\right)$ of xylanase, varying concentrations of xylan in substrate solution were used to perform enzyme assay and the $K_{m}$ and $K_{c a t}$ values were determined using a Lineweaver-Burk plot.

\section{RESULTS AND DISCUSSION}

\section{Primary screening}

The zone of hydrolysis was observed as bright halo around the colonies after flooding it with iodine solution which confirmed the presence of xylanase activity (Figure 1).

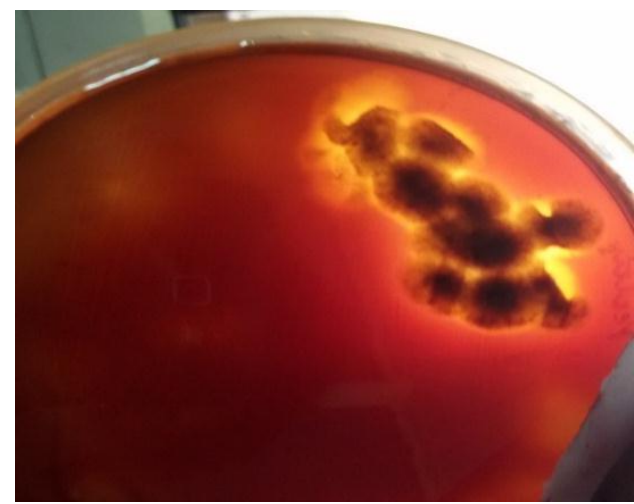

Figure 1: Primary screening for production of xylanase by A. pullulans on Potato Dextrose Agar (PDA) plate supplemented with $1 \%$ xylan. The halo around the colonies indicated the production of xylanase.

\section{Secondary screening}

The enzyme assay performed to evaluate the xylanase activity quantitatively revealed the activity of $8.23 \mathrm{U} / \mathrm{ml}$. Further optimization was done to enhance this activity by modifying various fermentation parameters.

\section{Optimization of physicochemical parameters Production medium}

The highest enzymatic activity of $11.78 \mathrm{U} / \mathrm{ml}$ was obtained in YM medium (Figure 2). YM medium has so far not been used for the production of xylanase from A. pullulans, however, the reports of using this medium for the maintenance of the culture exists [19].

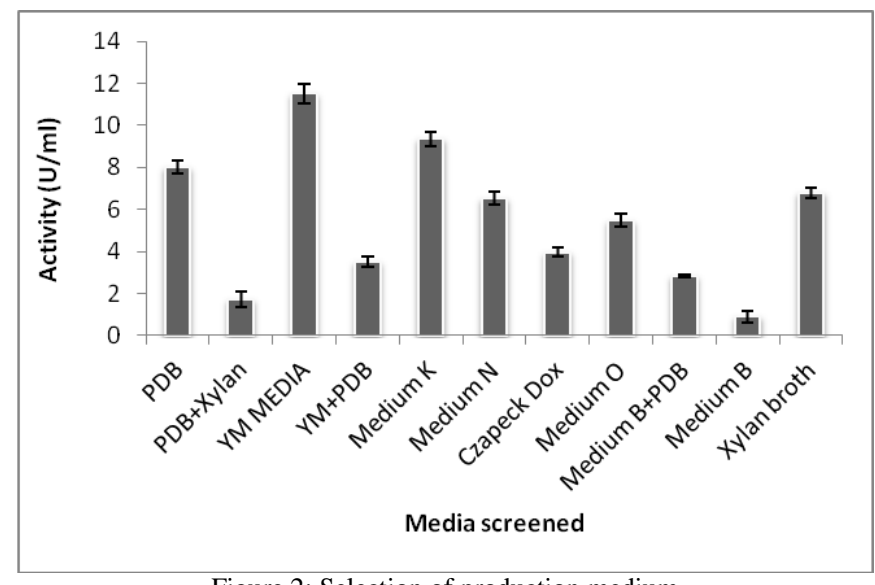

Figure 2: Selection of production medium

Production medium: PDB: Potato Dextrose Broth; YM medium: Yeast Mold medium; Medium K: formulated by Kar et al (2005); Medium N: formulated by Nair et al (2008); Medium O: formulated by Otero et al (2015); Medium B: formulated by Bravery et al (1968). Incubation time: 72 hours; Incubation temperature: $28 \pm 2^{\circ} \mathrm{C}$; Agitation speed: $120 \mathrm{rpm}$.

Values are Mean \pm SD of three observations.

\section{Incubation period}

The highest enzyme activity achieved was $14.69 \mathrm{U} / \mathrm{ml}$ on the second day of fermentation, thereafter a gradual decrease in activity was observed with increase in incubation time till seven days (Figure 3). Obtained results were in accordance with the reported results, where the highest yield of 2.73 $\mathrm{U} / \mathrm{ml}$ of xylanase from A. pullulans was observed after 2 days [17]. But, in multiple cases, 3-6 days have been accounted as the required production time for achieving maximum activity of xylanase from A. pullulans. For instance, some reports have suggested 3 and 5 days of incubation as the most suitable for maximum xylanase production, respectively, from $A$. pullulans $[18,19]$.

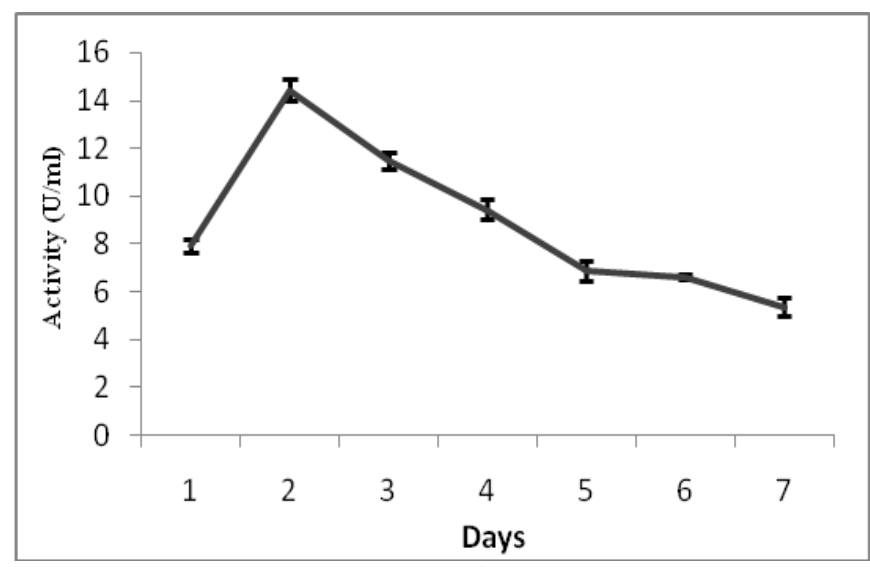

Figure 3: Optimization of incubation period.

Fermentation conditions: Medium: YM medium; Incubation temperature: $28 \pm 2^{\circ} \mathrm{C}$; Agitation speed: $120 \mathrm{rpm}$.

Values are Mean \pm SD of three observations. 


\section{pH}

The $\mathrm{pH}$ of 8.0 was found to be the best, supplementing the maximum xylanase activity $(17.00 \mathrm{U} / \mathrm{ml})$, followed by activity attained at pH $6.5(16.95 \mathrm{U} / \mathrm{ml})$ as shown in Figure 4. Similarly, some researchers have perceived $\mathrm{pH} 7.0$ to be the optimal $\mathrm{pH}$ for production from A. pullulans [17]. Though, reports of production at lower $\mathrm{pH}$ are also very prominent. As per the stated results, $\mathrm{pH}$ of 4.0-5.0 was found to be the best for achieving maximum activity of xylanase $[19,20]$. However, present isolate of A. pullulans was capable of giving maximum activity towards alkaline $\mathrm{pH}$. It is also noteworthy that the enzyme produced in this study has very appreciable activities even at higher alkaline $\mathrm{pH}$ which can prove to be of tremendous value when applied in numerous industries, especially paper and pulp industries.

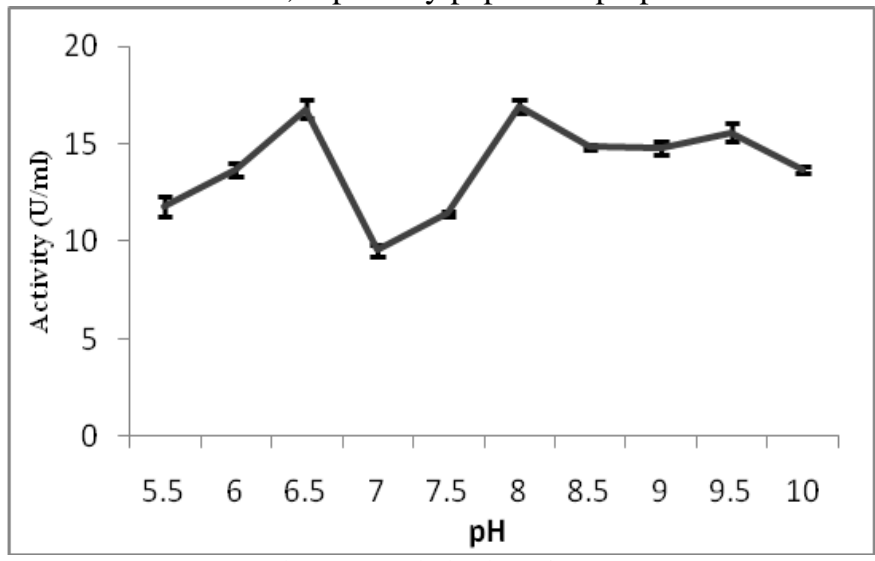

Figure 4: Optimization of $\mathrm{pH}$.

Fermentation conditions: Medium: YM medium; Incubation time: 72 hours; Incubation temperature: $28 \pm 2^{\circ} \mathrm{C}$; Agitation speed: 120 rpm.

Values are Mean \pm SD of three observations.

\section{Inoculum size}

Inoculum size of $0.25 \% \quad(125 \mu \mathrm{l})$ inoculated in the production medium was found to be the most appropriate for optimal production of xylanase, where the activity was found to be $17.49 \mathrm{U} / \mathrm{ml}$ (as shown in Figure. 5). Though, all the reported observations made indicated the use of larger inoculum sizes of $A$. pullulans was required to acquire the best enzymatic yield. For instance, 5\% inoculum size was found to be the best [17] or sometimes an even larger inoculum size of $10 \%$ has also been reported to be required for optimal production of xylanase by [20]. It indicates that the culture under study is efficient in terms of production with the least number of cells and capable of utilizing substrate more efficiently.

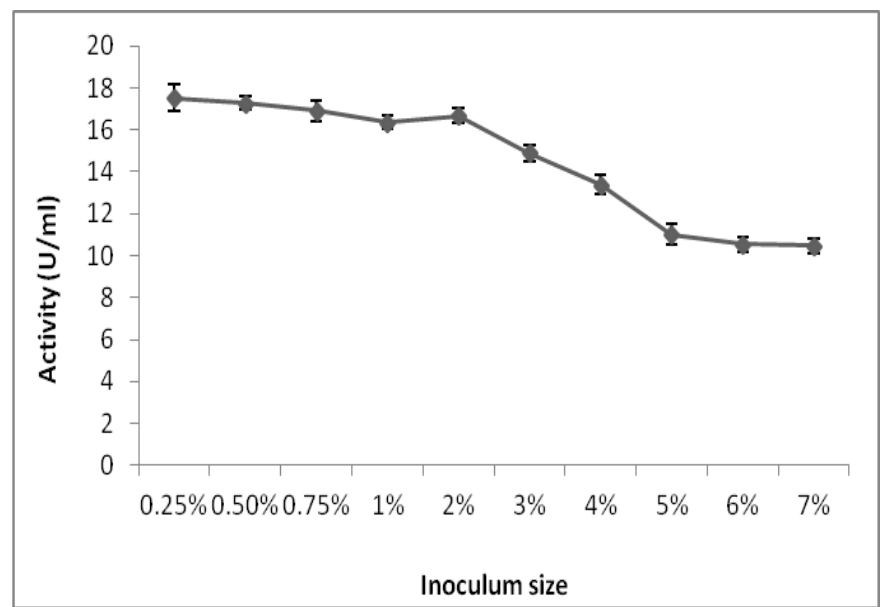

Figure 5: Optimization of inoculum size.

Fermentation conditions: Medium: YM medium; Incubation time: 72 hours; Incubation temperature: $28 \pm 2^{\circ} \mathrm{C}$; Agitation speed: 120 rpm. Values are Mean \pm SD of three observations

\section{Carbon Source}

A total of 13 carbon sources were screened for obtaining maximum enzyme activity. Glucose, which is originally present in the production medium, was found to be the most suitable carbon source for maximum xylanolytic activity of $17.70 \mathrm{U} / \mathrm{ml}$ (Figure. 6). Other reports have also suggested glucose as optimal carbon source for production of xylanase from Aspergillus awamori [21]. From this study, it can also be inferred that sugars with simpler structures are more readily utilized by this organism than complex polymeric sugars. However, when xylose was substituted as carbon source in the production medium, a fall in enzymatic activity was observed. Therefore, it can be inferred that presence of end product of the enzyme reaction alleviates enzyme production by $A$. pullulans, indicating regulation by negatively controlled repressible operon or feedback inhibition.

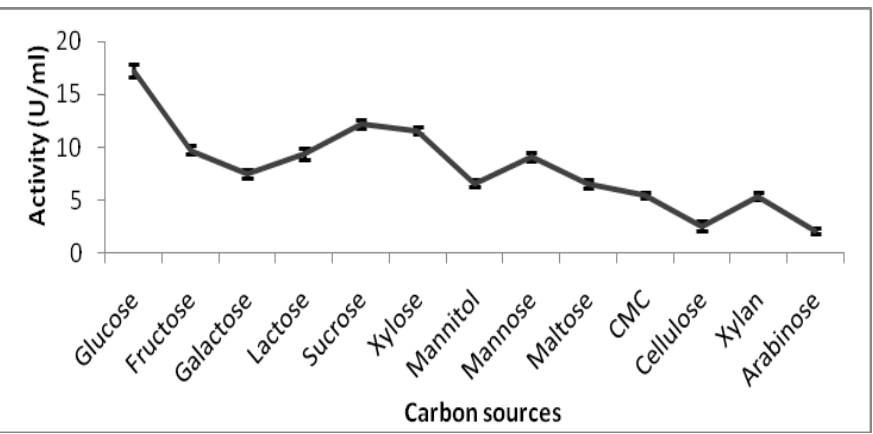

Figure 6: Selection of carbon source for production medium.

Fermentation conditions: Medium: YM medium; Incubation time: 72 hours; Incubation temperature: $28 \pm 2^{\circ} \mathrm{C}$; Inoculum size: $0.25 \%$; Agitation speed: $120 \mathrm{rpm}$. Values are Mean \pm SD of three observations. 


\section{Nitrogen source}

For selection of the most optimal nitrogen source, a total of 14 nitrogen sources were screened. The most optimal xylanolytic activity of $18.22 \mathrm{U} / \mathrm{ml}$ was achieved with Urea (Figure. 7). Almost similar yield of $17.85 \mathrm{U} / \mathrm{ml}$ was obtained when ammonium nitrate, an inorganic nitrogen source was used as sole nitrogen source.

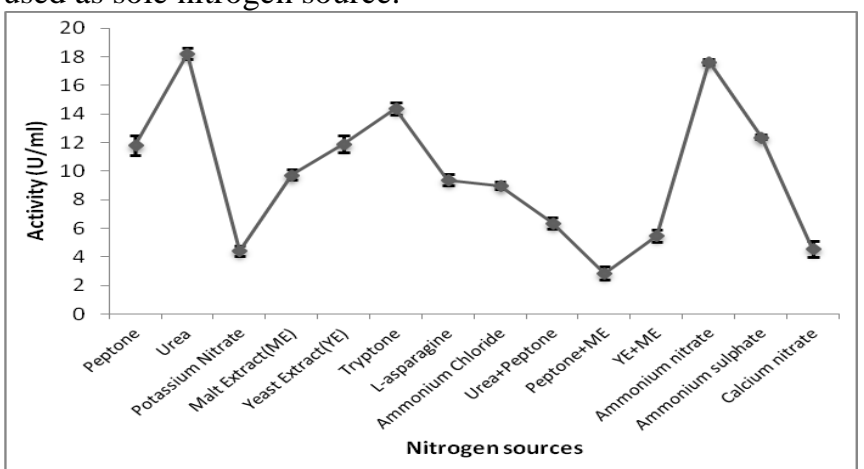

Figure 7: Selection of nitrogen source for production medium.

Fermentation conditions: Medium: YM medium; Incubation time: 72 hours; Incubation temperature: $28 \pm 2^{\circ} \mathrm{C}$; Inoculum size: $0.25 \%$; Agitation speed: $120 \mathrm{rpm}$. Values are Mean \pm SD of three observations.

\section{Effect of additives}

Many substances have been known to enhance the activity of the enzymes. Its effect, however, varies with different enzymes. The evaluation of effect of different additives led to conclusion that the surfactant, Tween 20 enhanced the enzymatic activity to $27.75 \mathrm{U} / \mathrm{ml}$ at $1 \mathrm{mM}$ concentration (Figure 8). The other additives which were studied, showed not much stimulatory effect on enzyme activity. At higher concentration $(2 \mathrm{mM})$ of each additive, the xylanolytic activity was observed to decrease manifolds.

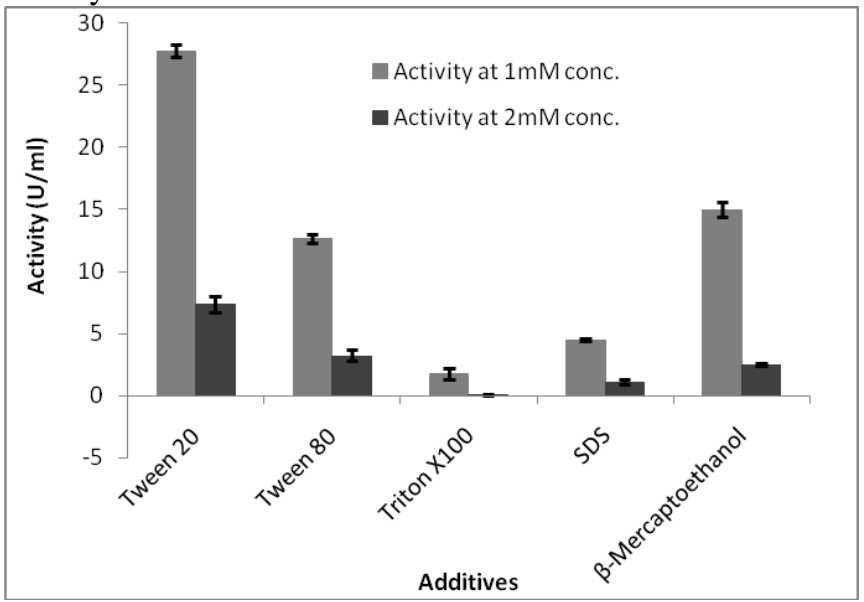

Figure 8: Effect of different additivies on xylanase produced by Aureobasidium pullulans.
Fermentation medium: Modified YM medium supplemented with additives ( $\mathrm{pH} 8.0,50 \mathrm{ml}, 0.25 \%$ inoculum). Fermentation conditions: $28 \pm 2^{\circ} \mathrm{C}$ at $120 \mathrm{rpm}$ for 2 days.

Values are Mean $\pm S D$ of three observations.

\section{Partial purification of xylanase}

Purification of crude enzyme extract was done by mixing the enzyme with different concentrations of ammonium sulfate. It was found that the maximum enzyme concentration was achieved at $60 \%$ saturation. Specific activity of the enzyme increased 2.44 folds during this step. The purification steps and yields have been summarized in the Table 1 below.

Table 1: Purification of extracellular xylanase from A. pullulans

\begin{tabular}{|c|c|c|c|c|c|}
\hline $\begin{array}{c}\text { Purification } \\
\text { step }\end{array}$ & $\begin{array}{c}\text { Total } \\
\text { activity }\end{array}$ & Protein & $\begin{array}{c}\text { Specific } \\
\text { Activity }\end{array}$ & $\begin{array}{c}\text { Purification } \\
\text { fold }\end{array}$ & $\begin{array}{c}\% \\
\text { recovery }\end{array}$ \\
\hline $\begin{array}{c}\text { Crude } \\
\text { supernatant }\end{array}$ & $35.8 \mathrm{U}$ & $4.5 \mathrm{mg}$ & $\begin{array}{c}7.99 \mathrm{U} \\
\mathrm{mg}^{-1}\end{array}$ & 1.00 & 100 \\
\hline $\begin{array}{c}\text { Ammonium } \\
\text { sulphate }\end{array}$ & $25.4 \mathrm{U}$ & $1.3 \mathrm{mg}$ & $\begin{array}{c}19.54 \mathrm{U} \\
\mathrm{mg}^{-1}\end{array}$ & 2.44 & 71 \\
\hline
\end{tabular}

Characterization of xylanase enzyme produced by $A$. pullulans

\section{Temperature optima and stability}

The temperature at which the maximum activity of xylanase obtained was $55^{\circ} \mathrm{C}(27.95 \mathrm{U} / \mathrm{ml})$ as shown in Figure 9A, after which the enzymatic yield decreased gradually with any further increase in temperature provided for enzyme reaction. The stability at $50^{\circ} \mathrm{C}$ and $55^{\circ} \mathrm{C}$ was also monitored for upto 90 minutes. As it can be seen in Figure 9B, that the enzyme under study was stable at both the temperatures till 60 minutes. Even after 90 minutes, almost $68.5 \%$ of the activity was retained at $50^{\circ} \mathrm{C}$. At $55^{\circ} \mathrm{C}, 79 \%$ of the total activity was retained by the enzyme. Hence, it can be inferred that the enzyme is the most stable at its temperature optima for almost an hour.

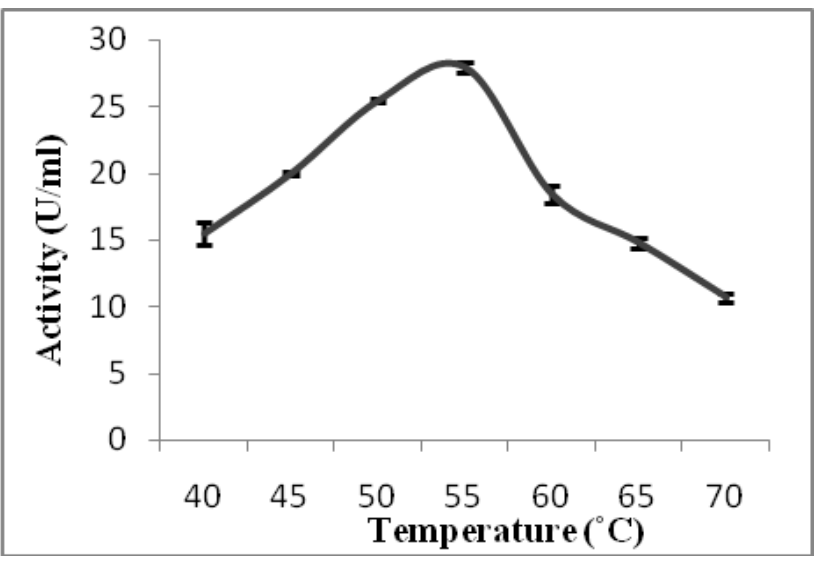

(A) 


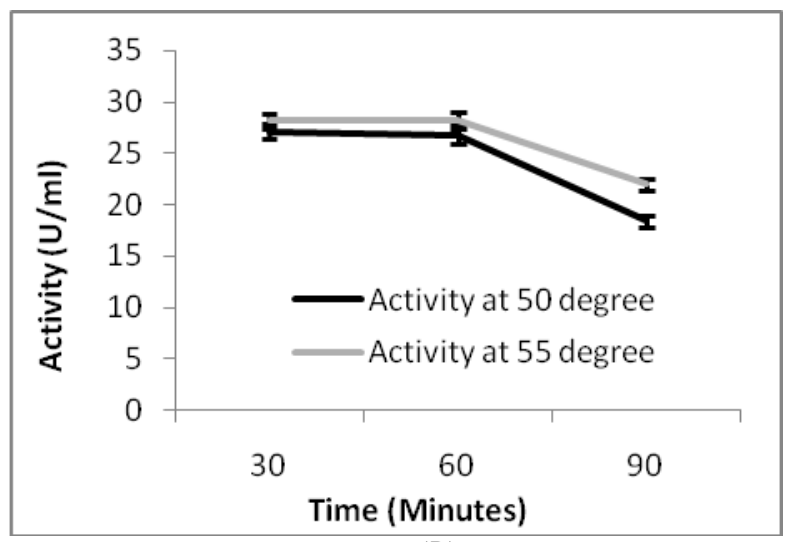

(B)

Figure 9 A) Temperature optima B) Stability of xylanase

\section{pH optimum and stability}

The influence of $\mathrm{pH}$ on the activity of xylanase was studied by varying the $\mathrm{pH}$ of the reaction system. The maximum activity of $28.14 \mathrm{U} / \mathrm{ml}$ was obtained at $\mathrm{pH} 6.0$ (Figure. 10A). This is a unique feature as almost all the studies done on xylanase from A. pullulans as per available literature indicate that their $\mathrm{pH}$ optimum below 6.0. For instance, it has been found that the $\mathrm{pH}$ optima of xylanase extracted from Aureobasidium pullulans CBS 58475 was at 3.5 [17]. Similarly, reports about Aureobasidium strain NRRL Y-231 1-1 suggest that it's $\mathrm{pH}$ optima was at 4.0 [22]. The $\mathrm{pH}$ optima of xylanase from A. pullulans var. melanigenum ATCC 20524 was stated at $\mathrm{pH} 2.0$ [23].

Next, the stability of enzyme at $\mathrm{pH} 5.5$ and at its optimal pH, i.e. at 6.0, was evaluated for a period of 90 minutes. It was established that that the xylanase under study is completely stable at both the $\mathrm{pH}$ for one hour (Figure. 10B). After 90 minutes, at $\mathrm{pH} 5.5$, the enzymes had only $60 \%$ of the activity retained while at $\mathrm{pH} 6.0$, about $85.7 \%$ activity was retained.

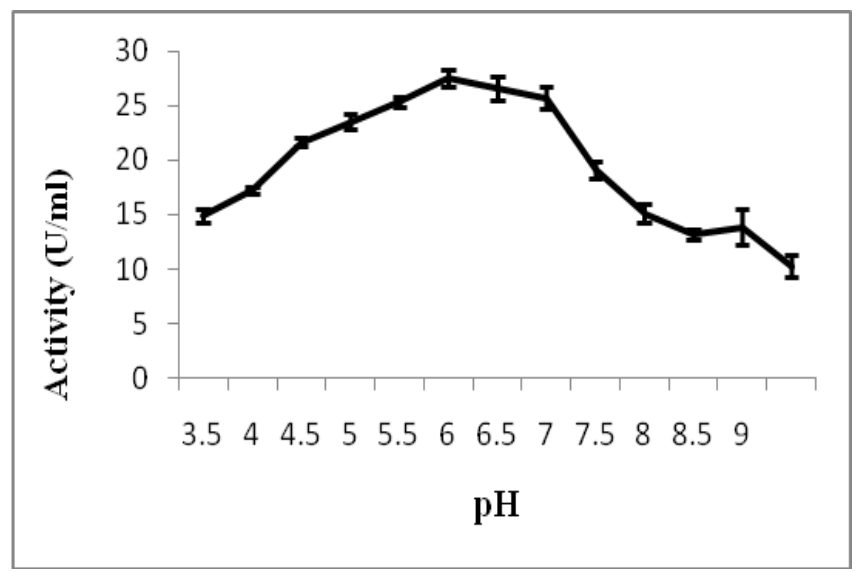

A)

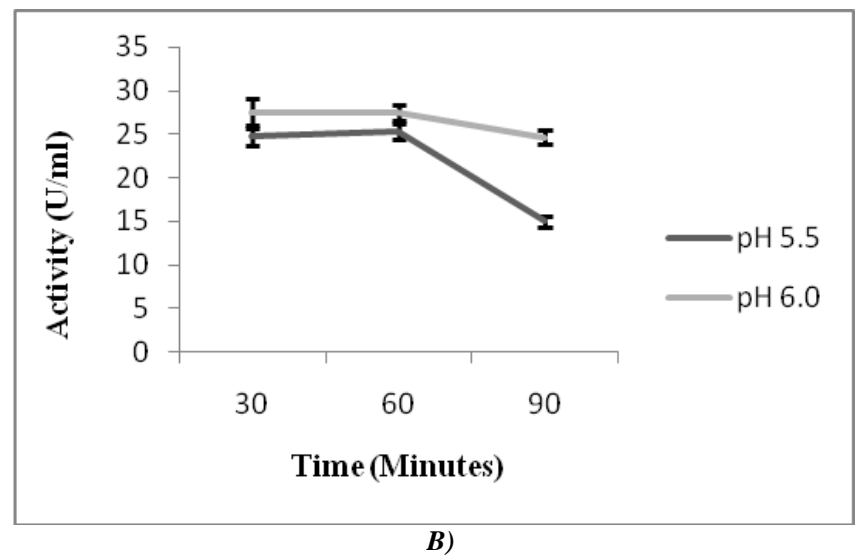

Figure 10 A) pH optima B) Stability of xylanase

\section{Effect of metal ions}

Metal ions play important roles in the biological function of many enzymes. The various modes of metal-protein interaction include metal-, ligand-, and enzyme-bridge complexes. Metals can serve as electron donors or acceptors [24]. This effect of metal ions on xylanase was studied and it was found that at $0.5 \mathrm{~mm}$ concentration, $\mathrm{Cu}^{2+}$ enhanced the activity; the enzyme had $168 \%$ activity when compared to control. While in the presence of other metal ions, the activity of the enzyme was hampered, however, $\mathrm{Na}^{+}$was found next to $\mathrm{Cu}^{2+}$ which retained $98 \%$ activity. Upon increasing the concentration of the metal ion to $1.0 \mathrm{mM}$, it was found in almost all the cases enzyme failed to exhibit any activity (Figure. 11). $\mathrm{Mg}^{2+}$ ion was found to be inhibiting the activity at all concentrations.

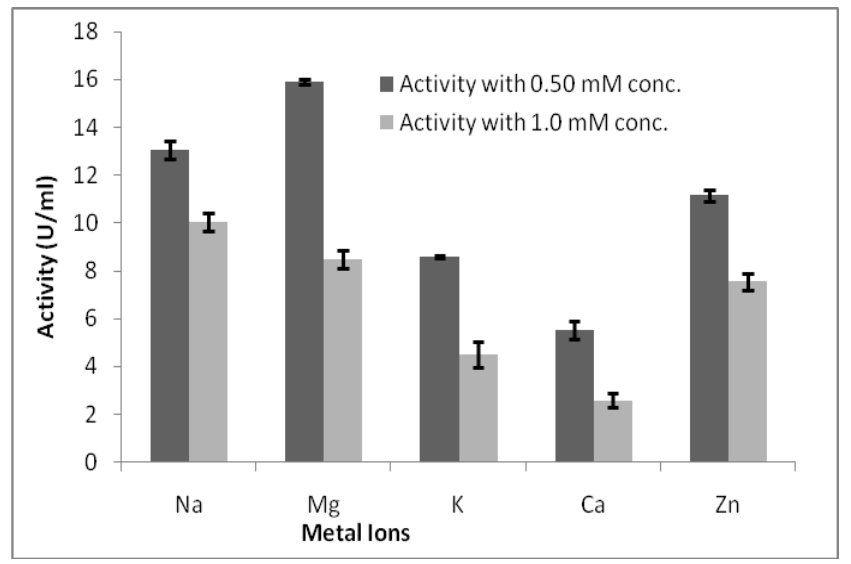

Figure 11: Effect of various metal ions on activity of xylanase

\section{Kinetic parameters}

The Lineweaver-Burk plot was made by evaluating the activity of xylanase at different substrate (beechwood xylan) concentrations (Figure 12). As it can be inferred from the graph, $\mathrm{K}_{\mathrm{m}}$ is $13.3 \mathrm{mg} \mathrm{ml}^{-1}$. As $\mathrm{K}_{\mathrm{m}}$ is inversely proportional to the binding affinity of enzyme to the substrate, the specificity in this case is found to be a little low. While, Vmax, which indicates maximum velocity of the enzyme in the presence of 
optimal amount of substrate which was found to be $5 \mu \mathrm{M} \cdot \mathrm{min}^{-1} \cdot \mathrm{ml}^{-1}$.

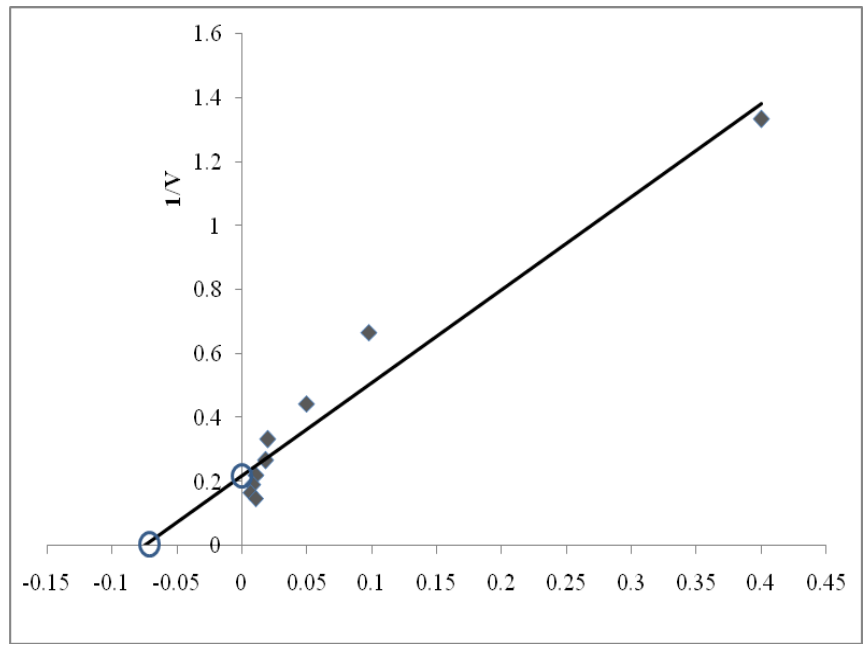

\section{CONCLUSION AND FUTURE SCOPE}

The Aureobasidium pullulans an important black yeast known mainly for exopolysaccharide production also possess potential for certain enzymes including xylanases. However, no concerted efforts have been made to explore its enzymatic potential. Therefore, In the present studies the xylanase producing potential of this indigenous species have been explored and various conditions affecting the enzyme production have been optimized. This resulted in overall three-fold increase in enzyme activity which is a significant enhancement. Besides, the studies pertaining to temperature and $\mathrm{pH}$ stability revealed the enzyme had better stability at alkaline $\mathrm{pH}$, which is unique and appreciable because enzyme with such features are constantly in demand by multiple industries. Thus, the present comprehensive study revealed a lot of potential for this enzyme to be explored further. And the future studies should consider genetically modifying the enzyme's binding domain so as to enhance its affinity for the substrate which would provide a tremendous hike in the activity and range of applications.

\section{ACKNOWLEDGMENT}

Authors are thankful to the Panjab University, Chandigarh for providing the research grant and necessary laboratory facilities for carrying out the present work.

\section{REFERENCES}

[1] A.D. Harris, C. Ramalingam, "Xylanases and its application in food industry: a review", Journal of Experimental Science, Vol.1, pp.1-11, 2010.

[2] E. X. F. Filho, J. Puls, M. P. Coughlan, "Biochemical characteristics of two endo- $\beta$-1,4-xylanases produced by Penicillium capsulatum", Journal of Industrial Microbiology, Vol.11,Issue 3,pp. 171-180, 1992.
[3] R. C. Kuhad, A. Singh, "Lignocellulose Biotechnology: Current and Future Prospects", Critical Reviews in Biotechnology, Vol.13, pp.151-172, 1993.

[4] F. Niehaus, C. Bertoldo, M. Kähler, G. Antranikian, "Extremophiles as a source of novel enzymes for industrial application, Applied Microbiology and Biotechnology, Vol.51, pp.711-729, 1999.

[5] D. M. Otero, C. L. Cadaval, L. M. Teixeira, C. A. Rosa, A. V. L. Sanzo, S. J. Kalil, "Screening of yeasts capable of producing cellulase-free xylanase", African Journal of Biotechnology, Vol.14, pp.1961-1969, 2015.

[6] P. Biely, "Microbial xylanolytic Systems", Trends in Biotechnology, Vol.3, pp. 286-290, 1985.

[7] M.L.T.M. Polizeli, A.C.S. Rizzatti, R. Monti, H.F. Terenzi, J.A. Jorge, D.S. Amorim, "Xylanases from fungi: properties and industrial applications", Applied Microbiology and Biotechnology, Vol.67, pp.577-591, 2005.

[8] J. Alvarez-Cervantes, E. M. Domínguez-Hernández, Y. MercadoFlores, A. O'Donovan, G. Díaz-Godínez, "Mycosphere essay 10: properties and characteristics of microbial xylanases", Mycosphere, Vol.87, pp.11-24, 2016.

[9] A. Walia, S. Guleria, P. Mehta, "Microbial xylanases and their industrial application in pulp and paper biobleaching: a review", 3 Biotech, Vol.7, pp.11, 2017.

[10] G. S. Hoog de, "Evolution of black yeasts: possible adaptation to the human host", Antonie van Leeuwenhoek, Vol.63, pp.105-109, 1993.

[11] Z. Chi, F. Wang, Z. Chi, L. Yue, G. Liu, T. Zhang, "Bioproducts from Aureobasidium pullulans, biotechnologically important yeast", Applied Microbiology and Biotechnology, Vol.82, pp. 793804, 2009.

[12] M. J. Bailey, J. Buchert, L. Viikari, "Effect of $p H$ on production of xylanase by Trichoderma reesei on xylan and cellulose-based media", Applied Microbiology and Biotechnology, Vol.40, pp.224-229, 1993.

[13] S. Kar, A. Mandal, P. K. Mohapatra, K. C. Mondal, B. R. Pati, "Production of cellulase-free xylanase by Trichoderma reesei SAF3", Brazilian Journal of Microbiology, Vol.37, pp.462-464, 2006.

[14] S. G. Nair, R. Sindhu, S. Shankar, "Purification and biochemical characterization of two xylanases from Aspergillus sydowii SBS 45", Applied Biochemistry and Biotechnology, Vol.149, pp.229243, 2008.

[15] F. Bravery, "Microbiological breakdown of cellulose in the presence of alternative carbon sources", Journal of the Science of Food and Agriulture, Vol.19, pp.133-135, 1968.

[16] W. B. Jakoby, "Crystallization as a purification technique", Methods in Enzymology, Vol.22, pp.248-252, 1971.

[17] S. Nasr, M. R. Soudi, A. F. Salmanian, P. Ghadam, "Partial optimization of endo-1, 4- $\beta$-xylanase production by Aureobasidium pullulans using agro-industrial residues", Iranian Journal of Basic Medical Sciences, Vol.16, pp.1245-1253, 2013.

[18] J. Myburgh, B. A. Prior, S. G. Kilian, "Production of xylanhydrolyzing enzymes by Aureobasidium pullulans", Journal of Fermentation and Bioengineering, Vol.72, pp.135-137, 1991.

[19] S. Yegin, " Xylanase production by Aureobasidium pullulans on globe artichoke stem: bioprocess optimization, enzyme characterization, and application in saccharification of lignocellulosic biomass", Preparative Biochemistry and Biotechnology, Vol.47, pp.441-449, 2016. 
[20] Priem, J. Dobberstein, C.C. Emis C, "Production of $\beta-1,4$ xylanase in continous culture by aureobasium pullulans CBS 58475", Biotechnology Letters, Vol.13, pp.149-154, 1991.

[21] C. Smith, T. M. Wood, "Xylanase production by Aspergillus awamori: Development of a medium and optimization of the fermentation parameters for the production of extracellular xylanase and $\alpha$-xylosidase while maintaining low protease production", Biotechnology and Bioengineering, Vol.38, pp.880$890,1991$.

[22] T. D. Leathers, "Purification and properties of xylanase from Aureobasidium", Journal of Industrial Microbiology, Vol.4, pp.341-358, 1988.

[23] K. Ohta, S. Moriyama, H. Tanaka, T. Shige, H. Akimoto, " Purification and characterization of an acidophilic xylanase from Aureobasidium pullulans and sequence analysis of the encoding genes", Journal of Bioscience and Bioengineering, Vol.92, pp.262270, 2001

[24] J. F. Riordan, "The role of metals in enzyme activity", Annals of Clinical and Laboratory Science, Vol.7, pp. 119-129, 1977.

\section{AUTHORS PROFILE}

Dr. Deepak K Rahi is professor at Department of Microbiology, Panjab University, Chandigarh. His research area of interest is fungal diversity, fungal metabolites and fungal enzymes especially their industrial uses. For last 15 years, he is actively working on fungal exopolysaccharides and their industrial applications. His research is focussed mainly on the development of fungal exopolysaccharides based Bioemulsifiers, Bioflocculants, Food thickners, Stablizers and Food Packaging films. He is also working on industrially enzymes of fungal origin especially the lignocellulolytic enzymes. The aim for this is to develop value added industrial products. He is having a teaching and research experience of 15 and 20 yrs respectively. He has supervised more than 30 M.Sc. dissertations and $4 \mathrm{PhD}$ thesis. $4 \mathrm{PhD}$. students are currently pursuing their $\mathrm{Ph} . \mathrm{D}$. He has more than 40 research publications including research papers, review articles and book chapters in national and international journals of repute. Besides, He has been member of various scientific scocities, AMI, MSI etc. $\mathrm{He}$ has been member of various Editorial boards, selection committees, acting as reviewer of many national and international journals. He has been awarded with various fellowships and awards. He has worked on and sanctioned various major research projects of various Govt. funding agencies like UGC, DBT, DST etc. 